\title{
Characterization of Metal Injection Molding (MIM) Feedstock Based on Water Soluble Binder System
}

\author{
Muhammad Hussain Ismail ${ }^{1}$, Norhamidi Muhamad² and Mohd Afian Omar ${ }^{3}$ \\ ${ }^{1}$ Faculty of Mechanical Engineering, UiTM Shah Alam, \\ Universiti Teknologi MARA \\ 40450 Shah Alam, Selangor, \\ Malaysia \\ ${ }^{2}$ Department of Mechanical and Materials Engineering, \\ Faculty of Engineering \& Built Environment, \\ Universiti Kebangsaan Malaysia \\ 43600 UKM Bangi, Selangor, \\ Malaysia \\ email:hamidi@eng.ukm.my \\ ${ }^{3}$ Powder Metallurgy Group, \\ Advanced Materials Research Centre (AMREC) \\ SIRIM Bhd \\ Lot 34, Jalan Hi-Tech 2/3 \\ Kulim Hi-Tech Park \\ 09000 Kulim, Kedah, \\ Malaysia
}

Received Date: $28^{\text {th }}$ August 2006 Accepted Date: $7^{\text {th }}$ March 2007

\begin{abstract}
Metal Injection Molding (MIM) is a new manufacturing technique especially to produce small and complex precision parts. Characterization of feedstock is one of the important tasks in order to evaluate the homogeneity level of the feedstock prepared and to control the quality of the parts during injection molding process. This paper attempts to investigate the characteristics of the MIM feedstock by performing rheological test using the feedstock consisted of $316 \mathrm{~L}$ stainless steel powder with a mean particle size of $12 \mu \mathrm{m}$ and a major fraction of water soluble binder system known as polyethylene glycol (PEG). Three different weight percentage of PEG at 65,75 and 85 respectively were used during the investigation. The viscosity of MIM feedstock at different temperatures and shear rates were measured and evaluated. Results show that increasing the PEG content would decrease the viscosity of the feedstock. The rheological properties of the feedstock showed that the proposed method of mixing is adequate to produce a homogeneous feedstock that is favorable for injection molding process.
\end{abstract}

Keywords: Homogeneous feedstock, rheological properties, pseudoplastic behaviour. 


\section{ABSTRAK}

Pengacuan suntikan logam (MIM) merupakan satu teknik pembuatan terbaru terutamanya untuk menghasilkan komponen-komponen logam yang bersaiz kecil dan bergeometri rumit. Pencirian bahan suapan merupakan salah satu ujian yang sangat penting terutamanya untuk memastikan bahawa bahan suapan yang dihasilkan adalah homogen dan juga untuk mengawal kualiti komponen jasad yang disuntik. Kertas kerja ini cuba mengkaji ciri-ciri bahan suapan MIM dengan menjalankan ujian reologi ke atas bahan suapan yang mengandungi serbuk logam keluli tahan karat jenis SS316L yang mempunyai saiz purata $12 \mu \mathrm{m}$ dengan pecahan terbesar bahan pengikat boleh larut dalam air yang dikenali sebagai polietilena glikol (PEG). Sebanyak tiga komposisi PEG yang berbeza berdasarkan peratusan berat ; 65, 75 dan 85 digunakan semasa uji kaji. Dalam kajian ini kelikatan bahan suapan pada suhu dan kadar ricih yang berbeza dikaji dan dinilai.Keputusan menunjukkan dengan penambahan PEG akan mengurangkan nilai kelikatan bahan suapan. Sifat-sifat bahan suapan yang diperolehi menunjukkan bahawa kaedah pencampuran yang digunakan adalah sesuai untuk menghasilkan bahan suapan yang homogen dan juga untuk tujuan proses penyuntikan.

Kata kunci: Bahan suapan homogen, ciri-ciri reologi, kelakuan pseudoplastik.

\section{INTRODUCTION}

At a time when market demands are extremely competitive, it is of great importance to obtain a cost-effective way of manufacturing a body without reducing the quality of the product. The importance on miniaturization, design flexibility and low cost has been stretching the capabilities of conventional manufacturing routes to the limit (Mohd Afian Omar 1999). An approach to meet such challenges has been the development of Metal Injection Molding (MIM). It is a new net shaping technology of powder metallurgy combined with the basic of conventional plastic injection molding (Anwar et al. 1995). It is an expanding technology especially for high volume production of small parts of complex shape, which would be expensive and/or difficult to be produced by other routes. Applications of MIM parts are concentrated in the areas of automotive components, business equipments, computer hardware, small arms components and sports related goods (Anwar et al. 1995a \& 1995b, Bakan et al. 1998).

Generally, MIM is composed of four main processes, namely a mixing process to prepare a homogenous metal-binder mixture, an injection moulding process, a debinding process to remove the binder and finally a sintering process. The process starts with the mixing of selected powder and binder at chosen volume ratio. The feedstock produced after mixing is moulded to produce a "green" compact using conventional plastic injection technique. The compact is subsequently processed to near full density by first removing the binder components known as debinding and then undergoing sintering. The sintering process is performed to remove pores which exist in the compact after the moulding operation.

MIM process consists of many steps before the final part could be produced, so there is ample opportunity for defects to be created. Thus, it is necessary to characterize the material being processed, from the initial powders and binders to the final component (lacocca 1994). Characterization of metal powder and binder components are the most important steps in understanding the whole process in MIM (German \& Bose 1997, lacocca 1994). The initial properties of MIM feedstock will dictate the final properties of the sintered part; thus, key parameters must be identified that can predict the success of the end product (Toru et al. 1997). Feedstock preparation is a very crucial process since quality deficiency of the feedstock cannot be corrected by subsequent processing adjustment (Supati et al. 2000). It is important to confirm that the prepared feedstock is homogeneous and free of any defect especially separation of powderbinder.

The viscosity of MIM feedstock plays a very important role in MIM as it is essential for allowing the particles to flow into the die cavity. 
Mold filling with the MIM feedstock is dependent on viscous flow of the mixture into the die cavity. This requires specific rheological characteristics (German 1990). Rhee et. al (1998) reported that the MIM feedstock had often been characterized rheologically by capillary rheometers especially at low shear rate. Good rheological properties of binder and feedstock are one of the keys to get green parts with uniform density and no defect, besides obtaining a successful debinding and sintering and high quality products ( $\mathrm{Li}$ et al. 1999). During injection molding practice the feedstock must exhibit pseudoplastic flow with a decreasing viscosity with increasing shear rate. This helps to reduce the needed temperature and pressure for successful molding. By using this rheological data, some insights on the scope of the parameters to be applied during the injection process could be obtained to control the quality of the green parts.

Feedstock characterization is a very important step in the MIM process. Many of the problems encountered in the actual molding of the component are created by incompatibility between the powder and binder. If this can detect early on, a great deal of wasted time and effort can be avoided. In order to obtain a good understanding on homogeneity level of the prepared feedstock, two characterization techniques were performed; first via rheological test as recommended by many MIM researchers (Cao et al.1991, Li et al.1999 \& 1997, Muhammad Hussain Ismail 2002) and second, direct examination of the sample under Scanning Electron Microscope (SEM). In this present study, the feedstock consists $316 \mathrm{~L}$ stainless steel powder and a major fraction of water soluble binder system known as polyethylene glycol (PEG) was used. It was reported that, binder system consisting of major fraction of PEG might reduce debinding time drastically without any defect on sample (Anwar et al. 1995a \& 1995b, Bakan et al. 1998, Mohd Afian Omar 1999) by using method of water extraction. These aspects have significant implications for the economics of the MIM process.

\section{EXPERIMENTAL PROCEDURE}

In this present study, 316L gas atomized stainless steel powder, which is spherical in shape was used with a mean particle size of approximately $12 \mu \mathrm{m}$. Figure 1 shows the morphology of the stainless steel powder used in the study. It clearly shows that the powder is almost spherical, which can provide a maximum packing density, exhibits good mouldability and lowers the powder/ binder viscosity, therefore it is preferred shape for MIM (German \& Bose 1997). Table 1 shows the particle size distribution of the powder measured using a laser particle analyzer. It can be seen that the powder had a relatively wide particle size distribution which is also desirable for efficient particle packing. The width of the particles size distribution affects mouldability. It was reported that a very wide or very narrow distribution is optimal for MIM (Mohd Afian Omar 1999). The intermediate width particle size distributions are generally considered as contribute to less shrinkage during sintering since the small particle sizes fit between the larger particles.

Powder loading of $63 \mathrm{vol} \%$ with a variable weight percentage (wt \%) of binder constituents; PEG and PMMA for $37 \mathrm{vol} \%$ were used. The compositions of the PEG were varied from 65,75 and 85 by weight percentage while the PMMA was reduced to balance the formulation. The stearic acid was kept constantly $5 \%$ wt for every composition prepared. Prior mixing process, PMMA emulsion was prepared by immersing it in acetone. This was done because the PMMA was received in the pellet form which difficult to be mixed together with particle powder. By preparing the emulsion, the mixing process became much easier since it could easily be mixed with particle powder. The mixing process was carried using a sigma blade mixer for about 1 hour and 35 minutes in order to eliminate the powder agglomeration. Since it was mixed in a long duration of time, the mixing was carried out at a minimum temperature to avoid degradation of the binder especially PEG component. After it cooled, the feedstock was then granulated using a crusher which provided a feedstock suitable for the rheological test. 


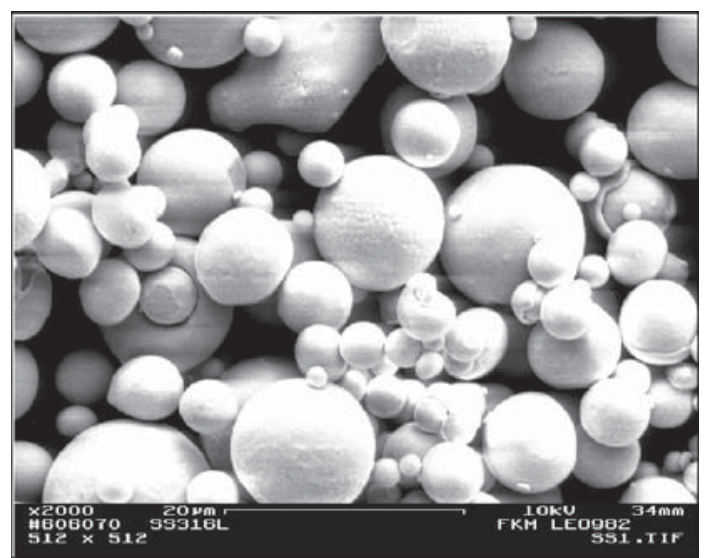

FIGURE 1. SEM micrograph of $316 \mathrm{~L}$ gas atomized stainless steel powder at 2000x

TABLE 1. The cumulative particle size distributions of stainless steel powder

\begin{tabular}{llllll}
\hline Volume $(\%)$ & $<\mathbf{1 0}$ & $<\mathbf{2 5}$ & $<\mathbf{5 0}$ & $<\mathbf{7 5}$ & $<\mathbf{9 0}$ \\
\hline Particle Size & \multirow{2}{*}{5.64} & 9.00 & 11.73 & 13.74 & 15.18 \\
Diameter $(\mu \mathrm{m})$ & & & & & \\
\hline
\end{tabular}

In order to obtain a good understanding on homogeneity level of the prepared feedstock, two characterization techniques were employed; first via rheological test as recommended by many MIM researchers (Cao et al. 1991, Li et al. 1997 \&1999, Rhee 1998) and second, through direct examination of the feedstock under Scanning Electron Microscope (SEM). A capillary rheometer model Shimadzu CFT-500D was used to investigate the rheological properties of the feedstock. The viscosity of the fine feedstock was measured at varying temperature and shear stress. The morphology of the feedstocks' prepared at different compositions was analyzed and from this morphological point of view; the most homogeneously mixed feedstock can be concluded. There were many evident (lacocca 1994, Mohd Afian Omar 1999) on the morphology observed showing the comparison between homogeneous and non-homogeneous feedstock. For the poorly mixed feedstock, the surface exhibits significant porosity, while the well-mixed feedstock shows no evidence of voids.

\section{RESULTS AND DISCUSSION}

Viscosity of MIM feedstock is very sensitive to temperature and powder content. At low temperature the feedstock viscosity is too high for standard injection molding process, meanwhile at high temperature; the binder might be too thin and may result in separation of powder and binder. The viscosity of MIM feedstock is quite higher than binder because of high volume fraction of powder particles. Addition of the powder composition in the feedstock will increase the shear between the powder and increase the viscosity. Thus, there should be a range of conditions over which MIM process is most viable. In this range, the feedstock must exhibit pseudoplastic flow with a decreasing viscosity with increasing shear rate and temperature.

Figure 2 shows the effect of feedstock viscosity with applied temperature at three different PEG compositions; 65\%, 75\% and $85 \%$ and two different pressures; $1 \mathrm{MPa}$ and 3 $\mathrm{MPa}$. It was observed that at the composition of $65 \%$ PEG, the lowest temperature that could be applied was $110^{\circ} \mathrm{C}$, while for both $75 \%$ PEG and $85 \%$ PEG were $70^{\circ} \mathrm{C}$ and $60^{\circ} \mathrm{C}$ respectively. The applied pressure of $1 \mathrm{MPa}$ was believed not sufficient to give the viscosity data in an appropriate region of 10 to $1000 \mathrm{~Pa}$.s, since most of the data give the viscosity reading greater than $1000 \mathrm{~Pa}$.s. At the pressure of $3 \mathrm{MPa}$, the viscosity data was more likely acceptable and give the viscosity data which was less than 1000 Pa.s. and desirable in MIM application. It shows that increasing the PEG content results in lowering the viscosity of the feedstock and thus reducing the applied temperature to make the feedstock flow through the die orifice. From the figure, it clearly shows that as the temperature and pressure increase, there is noticeable decrease in the feedstock's viscosity. When the material is 
heated, the particle or molecule of the material will move to form a new phase for example from solid to liquid. This phenomenon is mainly due to; (1) a decrease in the powder volume caused ranges between 100 and $10,000 \mathrm{~s}^{-1}$ and maximum viscosity for molding is 1000 Pa.s at the molding temperature (German 1990). Figure 3 shows the relation between viscosity and shear rate at three

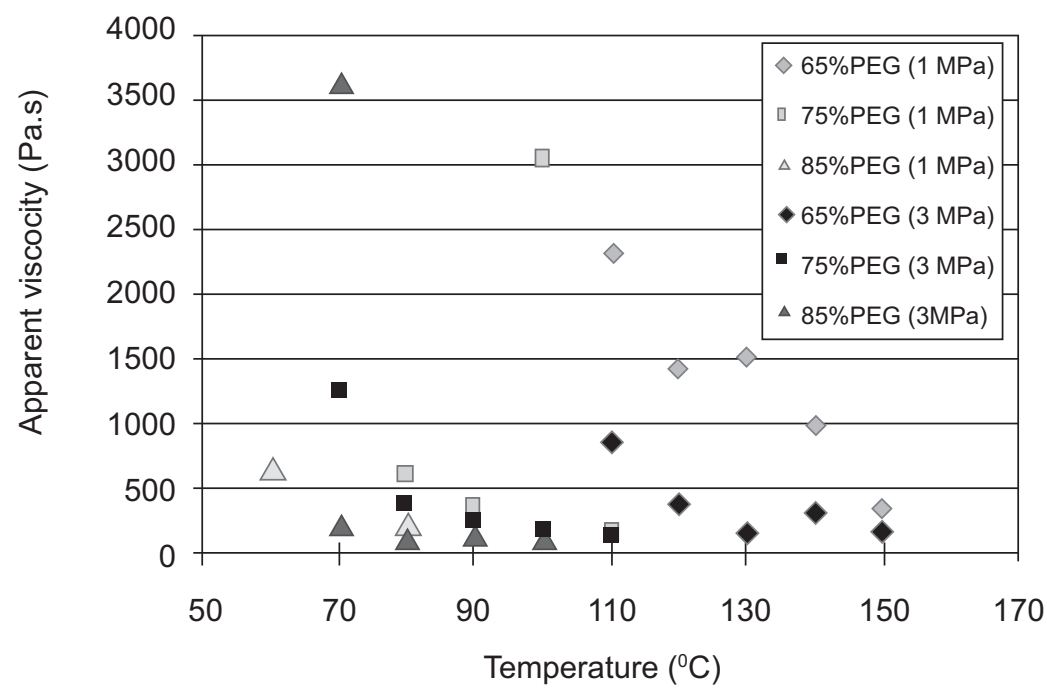

FIGURE 2. Effect of temperature on viscosity at pressures of $1 \mathrm{MPa}$ and $3 \mathrm{MPa}$

by greater expansion of the binder when heat is introduced; and (2) disentanglement of the molecular chain when more heat is distributed to fluctuate the random molecular structure.

From the figure, for the composition of $65 \%$ PEG, the viscosity decreases constantly as the temperature increases. The pattern of the curves is slightly the same for pressure of $1 \mathrm{MPa}$ and 3 MPa respectively. For the 75\%PEG composition, the viscosity is not as smooth as $65 \%$ PEG composition, whereby at temperature of $100^{\circ} \mathrm{C}$, the viscosity suddenly increased from $323 \mathrm{~Pa} . \mathrm{s}$ at $90^{\circ} \mathrm{C}$ to $3030 \mathrm{~Pa}$.s at $100^{\circ} \mathrm{C}$ and then suddenly drop to $169 \mathrm{~Pa}$.s at $110^{\circ} \mathrm{C}$. This phenomenon only occurred at the pressure of $1 \mathrm{MPa}$ and at the pressure of $3 \mathrm{MPa}$ the viscosity changes are more realistic and acceptable. The same phenomenon also happened to the $85 \%$ PEG composition. For both composition of $75 \%$ and $85 \%$ PEG composition, the fluctuation of the viscosity had been analyzed. The fluctuation occurred was believed due to the separation of metal powder from the binder matrix.This led to poor adhesion between powder and binders that flow through the die orifice.

In MIM process, the flow of the feedstock should follow pseudoplastic properties where the viscosity of feedstock decreases with the increasing of shear rate. Empirical studies have shown that the shear rate during molding usually different PEG compositions. It clearly shows that, with the increasing of temperature and shear rate, the viscosity decreases which exhibit the pseudolastic flow. From the figure, only 65\%PEG composition gave the result as required in MIM process which the viscosity ranges between 100 Pa.s and 1000 Pa.s at all temperature tested. Further analysis indicates that at low shear rate; i.e; $100 \mathrm{~s}^{-1}$ the viscosities for feedstock with $75 \%$ PEG and 85\% PEG, exhibit greater than 1000 Pa.s. Hence, this confirmed that the feedstock with composition of $75 \%$ PEG and $85 \%$ PEG are not feasible for injection molding.

Figure 4 shows the morphology of the feedstock at three different PEG compositions; $65 \%, 75 \%$ and $85 \%$ at the magnification of 1000x. A properly mixed feedstock consists of homogeneous powder dispersion in a matrix of binder, with no agglomeration and no internal porosity and the binder filling the spaces between the particle powders and coating each powder. It is clear that all the feedstock show evidence of binder covering the particle powder. Also note that there are few voids for all samples prepared, but the $85 \%$ PEG exhibits significant porosity as compared to $65 \%$ and $75 \%$ PEG respectively. It also shows that some of the powder for the $85 \%$ PEG was separated from the matrix of binder. The formation of voids was believed due to the improper adhesion between PEG and PMMA at the higher amount of PEG. 


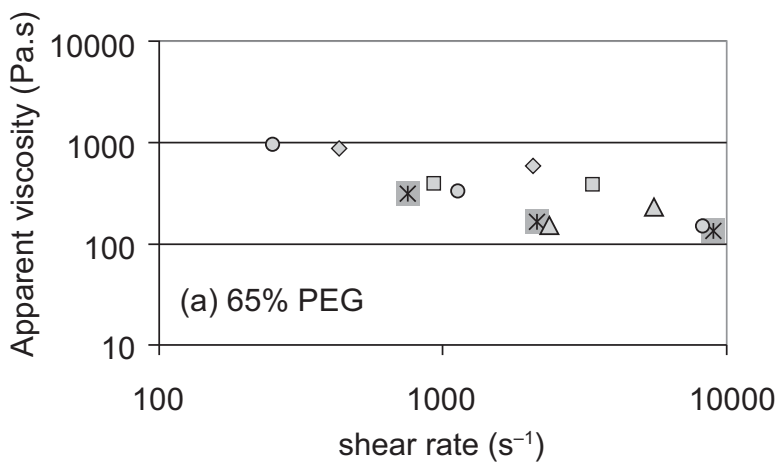

$\diamond 110 \operatorname{deg} C \square 120 \operatorname{deg} C \triangle 130 \operatorname{deg} C \circ 140 \operatorname{deg} C * 150 \operatorname{deg} C$

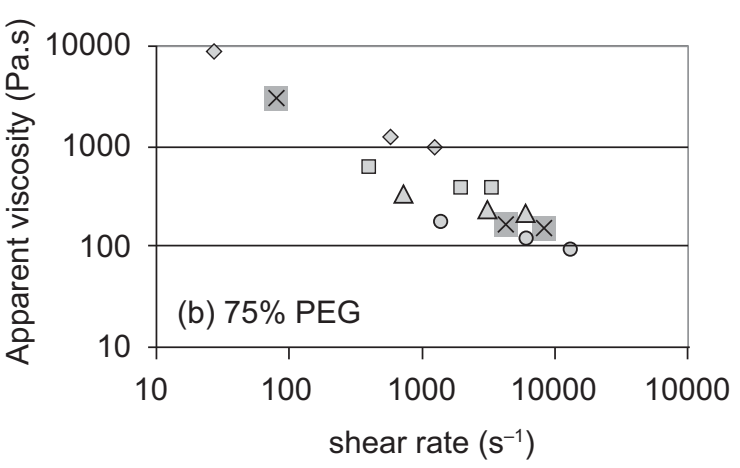

$\diamond 70 \operatorname{deg} C \square 80 \operatorname{deg} C \triangle 90 \operatorname{deg} C \times 100 \operatorname{deg} C \circ 110 \operatorname{deg} C$

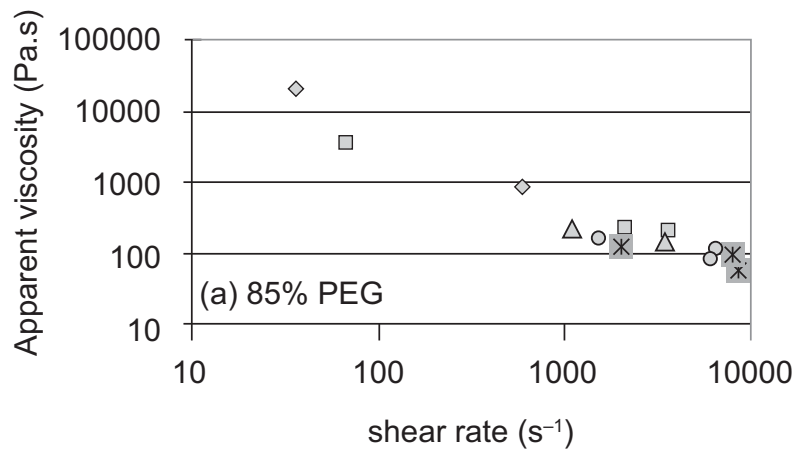

$\diamond 60 \operatorname{deg} C \square 70 \operatorname{deg} C \triangle 80 \operatorname{deg} C \circ 90 \operatorname{deg} C * 100 \operatorname{deg} C$

FIGURE 3. Relation between viscosity and shear rate

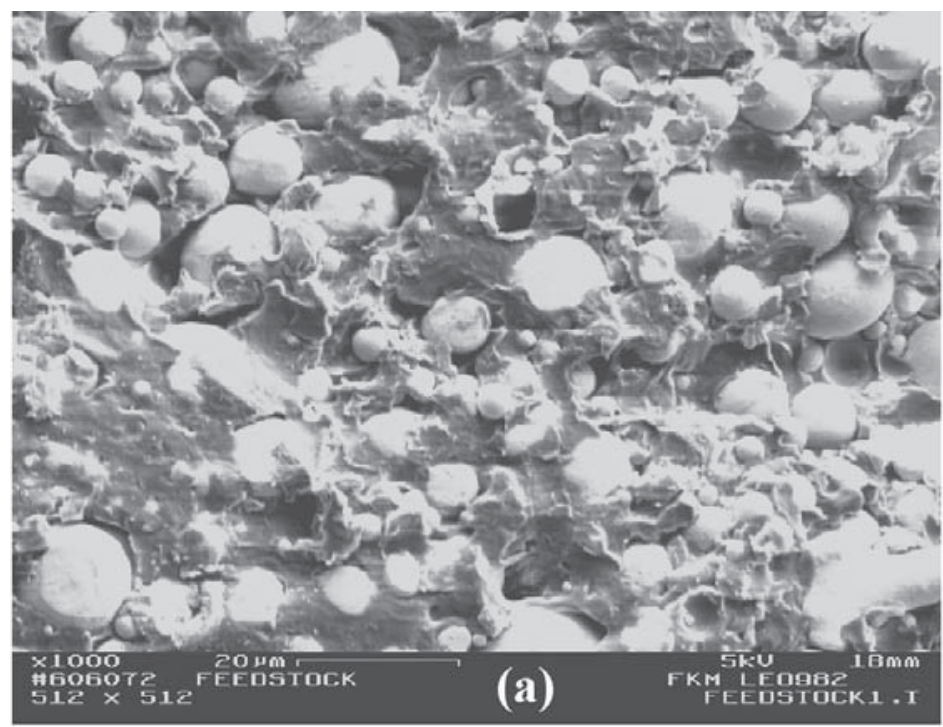



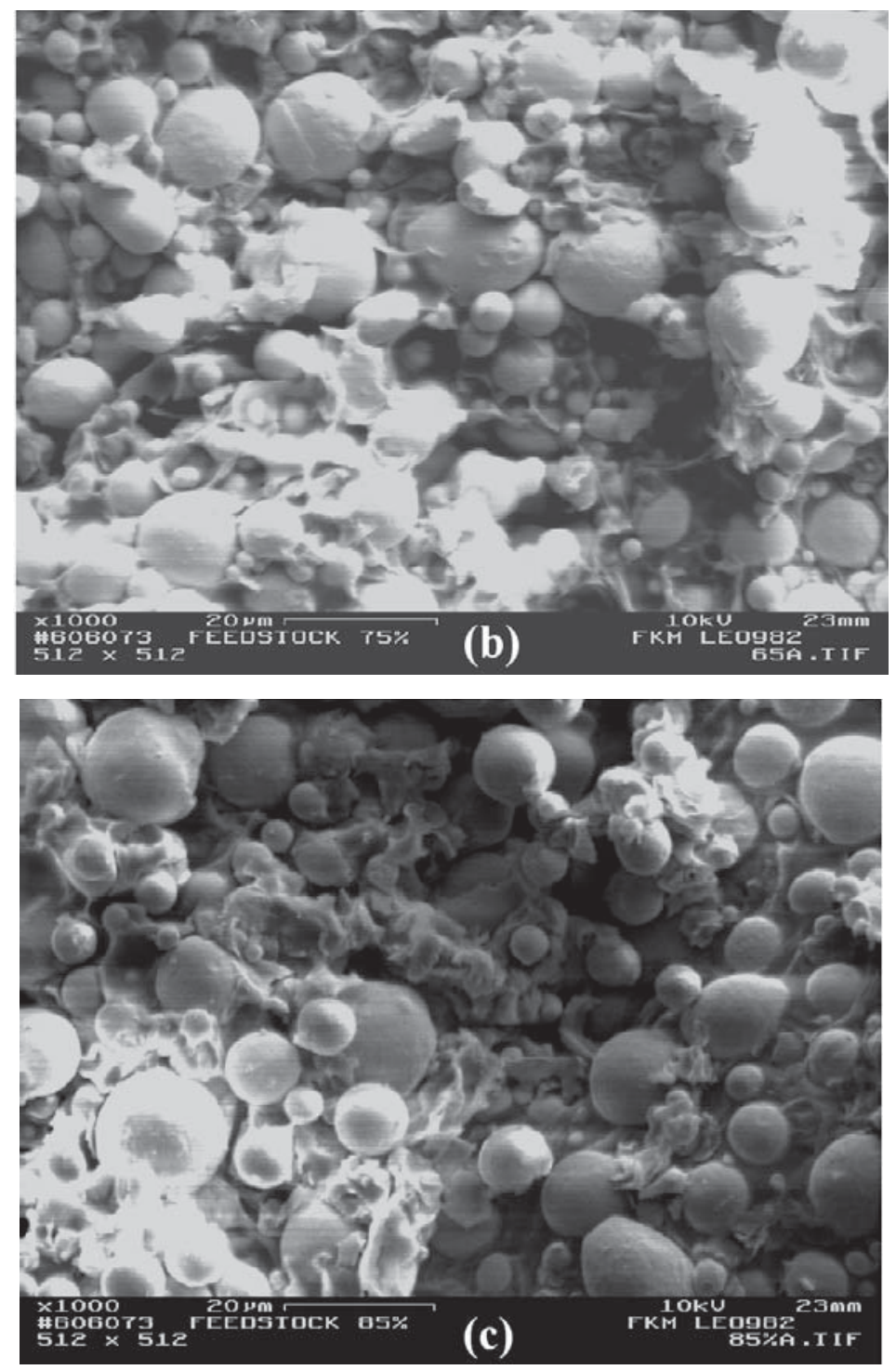

FIGURE 4. Scanning electron micrograph of feedstock at the magnification of $1000 x$ (a) $65 \%$ PEG, (b) $75 \%$ PEG and (c) $85 \%$ PEG

The less amount of PMMA in the feedstock had weakened the adhesion property to the powder and might result in low green strength.

\section{CONCLUSIONS}

The study has shown clearly that the composite binder, composed of PEG and PMMA, works successfully for fine $316 \mathrm{~L}$ stainless steel powder. From the rheological study, it can be concluded that all the data from all three PEG compositions followed the pseudoplastic behavior which has viscosity almost in the range of 100 Pa.s to 1000 Pa.s. Increasing the PEG content results in decreasing in viscosity and increase in shear rate of the feedstock. It is concluded that the $75 \%$ and $85 \%$ PEG composition cannot stand for high pressure which made it flow rapidly due to very low viscosity. Feedstock of $65 \%$ PEG was observed to be homogeneously mixed as it exhibit the recommended rheological characteristics. SEM micrographs showed significantly the differences between good and poor feedstock. For homogeneous feedstock especially at the composition of $65 \%$ PEG, the powder was properly mixed and the powder was fully coated by the binder. The powder also dispersed homogeneously in a matrix of binder, with no agglomeration observed.

\section{ACKNOWLEDGEMENTS}

The authors would like to acknowledge the Institute of Research, Development and Commercialization (IRDC), Universiti Teknologi MARA for the fund of the project. 


\section{REFERENCES}

Anwar, M. Y, Davies, H. A, Messer P. F. \& Ellis, B. 1995a. A Novel Binder System for Powder Injection Molding. Advances in Powder Metallurgy and Particulate Materials 2(6): 15-25.

Anwar, M. Y, Davies, H. A, Messer P. F. \& Ellis, B. 1995b. Preparation of Feedstock for PIM by Using A New Binder System. Advances in Powder Metallurgy and Particulate Materials 2(6): 30-45.

Bakan, H. I, Jumadi, Y, Messer P. F, Davies, H. A \& Ellis, B. 1998. Study of Processing Parameter for MIM Feedstock Based on Composite PEG, PMMA Binder. Powder Metallurgy, 4:289-291.

Cao, M. Y, Rhee, B. O \& Chung, C. I. 1991. Usefulness of the Viscosity Measurement of Feedstock in Powder Injection Molding. Powder Injection Molding, 2:59-74.

German, R. M. \& Bose, A. 1997. Injection Molding of Metals and Ceramics. New Jersey: Metal Powder Industries Federation.

German, R. M. 1990. Powder Injection Molding. New Jersey: Metal Powder Industries Federation.

Iacocca, R. G. 1994. A Critical Assessment of Characterization Tests Needed to Support Powder Injection Molding Component Fabrication. Reviews In Particulate Materials, 2: 269-313.

Li, Y., Huang, B. \& Qu, X. 1999. Improvement of Rheological and Shape Retention Properties of Wax-Based MIM Binder by Multi-Polymer Components. Trans. Nonferrous Met. Soc. China, 9(1):22-29.

Li, Y., Qu, X., Huang, B. \& Qiu, G. 1997. Rhelogical Properties of Metal Injection Molding Binder and Feedstock. Trans. Nonferrous Met.Soc.China, 7(3): 103-107.

Mohd Afian Omar. 1999. Injection Moulding of 316L Stainless Steel and NiCrSiB Alloy Powders Using a PEG/PMMA Binder. Ph.D Thesis. University of Sheffield, England.

Muhammad Hussain Ismail.2002. Kesan Pembebanan SerbukLogamTerhadapFenomenaPemprosesan Dalam Pengacuan Suntikan Logam. M.Sc Thesis. Universiti Kebangsaan Malaysia.

Rhee, B. O, Jung, Y. C. \& Lee, J. H. 1998. The Rheological Characterization of PIM Feedstocks at Low Shear Rates. Powder Injection Molding Technologies : 79-91.

Supati. R, Loh. N. H, Khor, K. A \& Tor, S. B. 2000. Mixing And Characterization Of Feedstock For Powder Injection Molding. Materials Letters Elsevier Science: 109-114.

Toru, S., Yoichi, M., Krisada, W., Tosio, S. \& Hideaki, Ni. 1997. Characterization of the Molding Methods and the Binder System In The MIM Process. Elseveir Science S. A:223-228. 